\title{
EFFECTS OF HORMONES ON REPRODUCTION IN RATS FED A DIET DEFICIENT IN RETINOL (VITAMIN A ALCOHOL) BUT CONTAINING METHYL RETINOATE (VITAMIN A ACID METHYL ESTER)
}

\author{
W. A. GOWARD, J. MaG. HOWELL, G. A. J. PITT AND J. N. THOMPSON \\ Departments of Biochemistry and Veterinary Pathology, University of Liverpool
}

\section{(Received 18th Fanuary 1966)}

\begin{abstract}
Summary. The observations of Thompson, Howell \& Pitt (1964), that male and female rats maintained on diet deficient in vitamin $\mathrm{A}$ but containing retinoic acid (vitamin A acid, see page 310) are unable to reproduce, have been confirmed. The development of the testicular lesions in male rats was not prevented by injections of FSH or testosterone propionate, and injections of oestrone and progesterone, alone or in combination, did not prevent resorptions in pregnant females. Small amounts of retinyl acetate (vitamin A acetate) prevented the development of reproductive lesions in both males and females. It seems unlikely that the failure of retinoic acid to support normal reproduction in the rat can be explained in terms of a known endocrine insufficiency.
\end{abstract}

\section{INTRODUCTION}

When rats reared on a vitamin A-free diet are given supplements of retinoic acid they do not suffer the overt and fatal effects of vitamin A deficiency: they grow well, have a normal life-span and appear to be healthy (Arens \& van Dorp, 1946; Sharman, 1949; Redfearn, 1960). Retinoic acid, however, unlike the true vitamin, retinol (vitamin A alcohol) does not maintain vision (Dowling \& Wald, 1960) or reproduction (Thompson, Howell \& Pitt, 1961a, b, 1964; Juneja, Murthy \& Ganguly, 1964; High, Moore, Collins \& Frazier, 1964). It has been suggested that the lesions seen in the reproductive tract of rats maintained on a diet deficient in retinol but containing retinoic acid represent a specific effect of vitamin A deficiency on these structures (Howell, Thompson \& Pitt, 1963, 1964).

Male rats maintained on vitamin A free diets containing retinoic acid develop testicular lesions 5 to 8 weeks after weaning, that is at a time when their body reserves of retinol and retinyl esters are exhausted. Spermatogenesis ceases, the cells of the seminiferous epithelium are sloughed and eventually the lumen of the tubules becomes obliterated by Sertoli cells (Howell et al., 1963). Female rats reared on a similar diet have regular oestrous cycles and mate with normal males, but pregnancy is invariably terminated in foetal resorption. The 
earliest detectable lesion was necrosis of cells at the edge of the placenta during the 15th or 16th day of pregnancy (Howell et al., 1964).

Although the inability of the acid to function in reproduction has, as yet, no certain biochemical explanation, the good growth, the longevity and absence of metaplastic change in epithelia in animals fed retinoic acid permit investigation on the uncomplicated reproductive disorders. In completely deficient animals untreated with retinoic acid, other factors such as inanition and infection have complicated the lesions (Mason, 1939).

This paper reports experiments in which steroid and pituitary sex hormones were administered to rats fed a vitamin A-free diet supplemented with methyl retinoate. The results of these experiments indicate that the reproductive failure in animals maintained with methyl retinoate is unlikely to be a secondary manifestation of an abnormality in the endocrine system.

\section{MATERIALS AND METHODS}

\section{Animals, diets and experimental techniques}

Albino Sprague-Dawley rats were bought as 21-day-old weanlings weighing 40 to $60 \mathrm{~g}$. They were fed from the outset the retinol-free Diet II described previously (Thompson et al., 1964) either unsupplemented or containing methyl retinoate $(3 \mu \mathrm{g} / \mathrm{g}$ diet $)$ as indicated in the text. Supplements of retinyl acetate were dissolved in $0.2 \mathrm{ml}$ arachis oil and were administered orally from a pipette; crystalline steroid hormones were injected subcutaneously in $0.2 \mathrm{ml}$ arachis oil, and FSH (purchased from Nutritional Biochemical Corporation, Cleveland 28, Ohio) was injected subcutaneously in $0.2 \mathrm{ml}$ physiological saline.

Female rats were mated with males of the same strain that had been reared on a normal laboratory diet. Vaginal smears were obtained daily throughout the mating periods and subsequent pregnancies. The first day of pregnancy was taken to be the day on which spermatozoa were found in the vaginal smear.

During mating three female rats were placed with each male. After individual females had mated they were removed from the male and caged in groups of three or four. If, by the 18th day of pregnancy their daily weight gain indicated that pregnancy had been maintained, they were caged individually with nesting materials.

Resorptions were characterized by an initial increase in weight followed by a sharp decrease preceded by vaginal bleeding which persisted for several days. Such animals did not abort and no foetuses were delivered.

In accordance with the rules for the nomenclature of vitamins approved by the Commission on the Nomenclature of Biological Chemistry of the International Union of Pure and Applied Chemistry (1960), vitamin A alcohol, vitamin $A$ acid and vitamin $A$ esters will be called retinol, retinoic acid and retinyl esters respectively. The term vitamin A will sometimes be employed in a more general nutritional sense.

\section{Post-mortem and histology}

Animals were killed by chloroform inhalation. Material for histological examination was fixed in Bouin's fluid as soon as possible after death. Testes 
and seminal vesicles were weighed before fixation. Tissues were embedded in paraffin wax; sections were cut at $4 \mu$ and stained with haematoxylin and eosin.

\section{Administration of $\mathbf{F S H}$ to male rats}

Fifty male rats were prepared for the experiment by rearing them from weaning on the basic diet supplemented with methyl retinoate. To establish the time at which the body stores of retinol acquired during lactation had been exhausted another five rats were simultaneously fed unsupplemented basic diet. The latter group of animals, group I, displayed typical signs of vitamin A deficiency (failure to gain weight and xerophthalmia) after 45 days on the diet. At this time they were killed together with ten rats, group II, from the main experimental group.

The remaining forty rats, which were growing well and appeared healthy, were separated into four groups of ten animals. One group of animals was left untreated, group III ; two other groups, IV and V, were given $5 \mu$ g retinyl acetate daily; the rats in group $\mathrm{V}$ were also given $1 \mathrm{mg}$ FSH each day, and rats in group VI were given FSH alone. After 30 days' treatment all the animals were killed and their testes and seminal vesicles were examined.

\section{Administration of testosterone propionate to male rats}

Forty male weanling rats were fed the basic diet and methyl retinoate. Six rats fed the unsupplemented diet, group VII, were killed when showing signs of vitamin A deficiency after 39 days on the diet. At this stage of the experiment the forty animals fed methyl retinoate were separated into four groups of ten. One group was left untreated, group VIII; animals in the other groups were given $5 \mu \mathrm{g}$ retinyl acetate/day, group IX; or $5 \mu \mathrm{g}$ retinyl acetate and $1 \mathrm{mg}$ testosterone propionate/day, group $\mathrm{X}$; or $\mathrm{I} \mathrm{mg}$ testosterone propionate alone, group XI. After 28 days of treatment all the rats were killed and their testes and seminal vesicles were examined.

\section{Administration of progesterone and oestrone to pregnant rats}

One hundred and ten female rats were reared on the basic diet supplemented with methyl retinoate. Six rats, given unsupplemented diet, showed signs of vitamin A deficiency after 46 days on the diet indicating exhaustion of their body reserves of retinol and retinyl esters.

The rats, fed methyl retinoate, grew well and, when 4 months old, they were mated with normal males. Seven groups of ten mated rats were thus obtained. These rats were given retinyl acetate, steroid hormones or both, from the 8th to 20th days after mating. Details of the treatments are shown in Table 2.

\section{RESULTS}

\section{The effects of FSH and testosterone propionate on male rats}

The testes and seminal vesicle weights and the histological appearance of the seminiferous epithelium of these rats are summarized in Table 1 . The testes were classified according to their histological appearance into five categories: A, B, C, D and E (see Table 1 and Pl. 1, Figs. I to 4). 


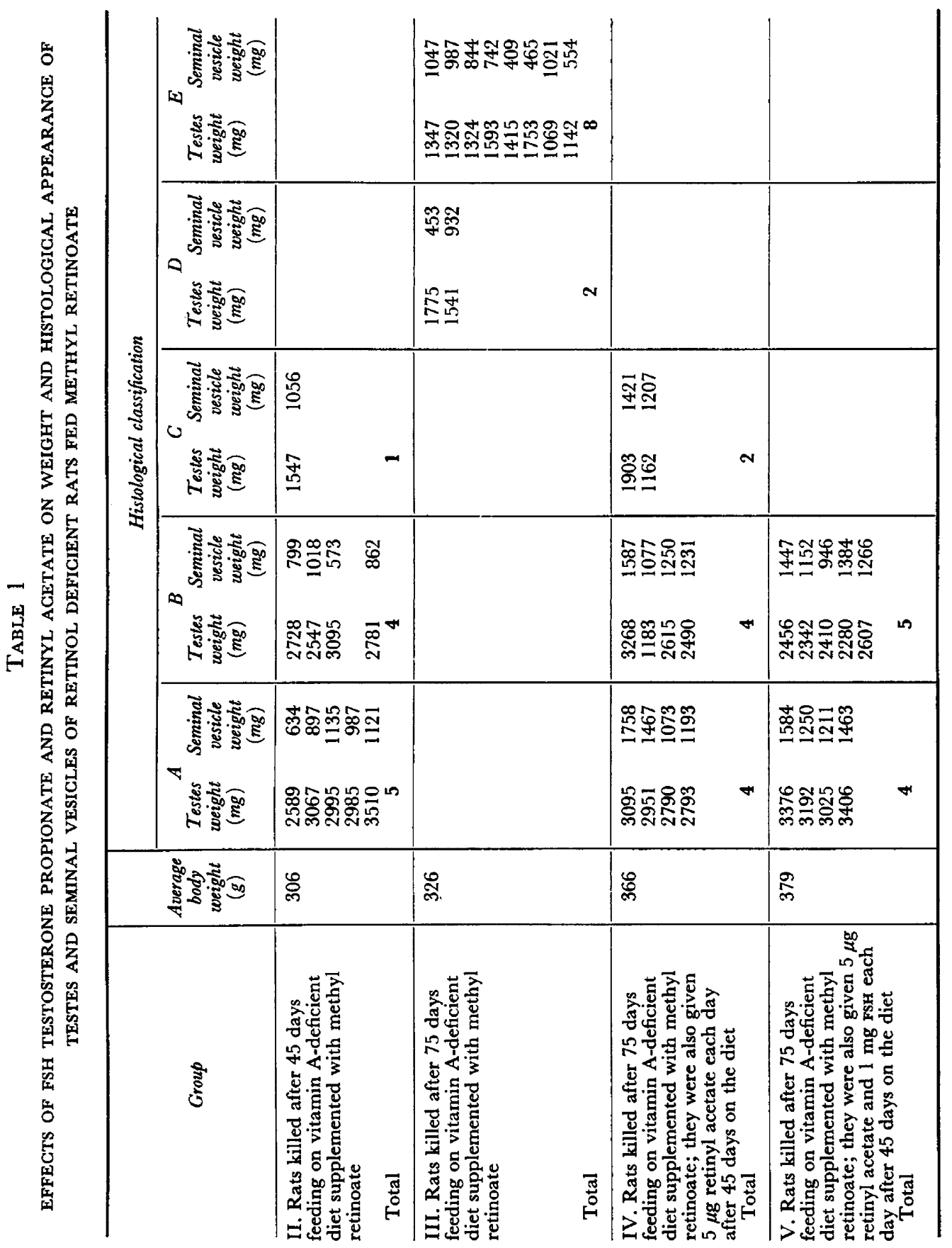




\begin{tabular}{|c|c|c|c|c|c|}
\hline \multicolumn{2}{|c|}{ 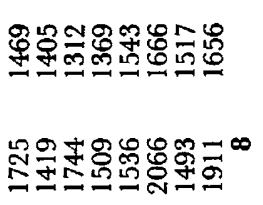 } & 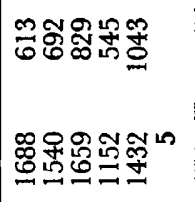 & & & 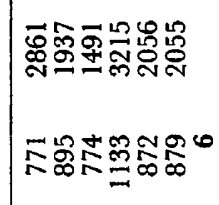 \\
\hline 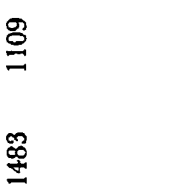 & $m$ & 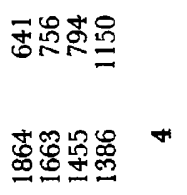 & & & 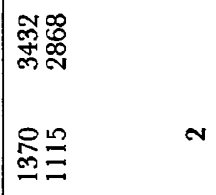 \\
\hline $\begin{array}{l}\stackrel{\circ}{=} \\
\text { सें }\end{array}$ & - & 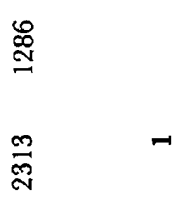 & $\begin{array}{l}0 \\
0 \\
0 \\
0 \\
\varrho\end{array}$ & 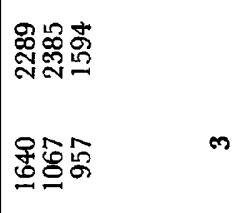 & 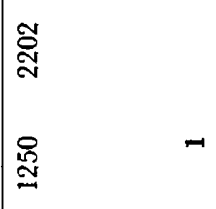 \\
\hline & & & 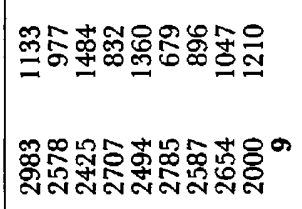 & 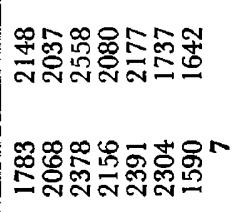 & $\begin{array}{l}\stackrel{2}{5} \\
\underset{7}{2}\end{array}$ \\
\hline \& & & 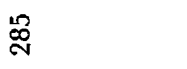 & \&్ల & $\stackrel{\infty}{\mathscr{N}}$ & $\stackrel{\infty}{\stackrel{N}{N}}$ \\
\hline 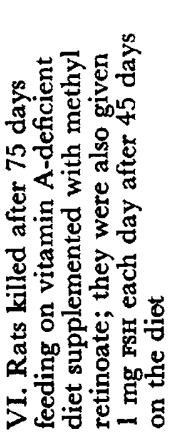 & 胥 & 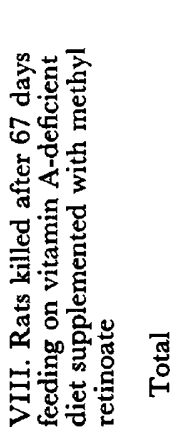 & 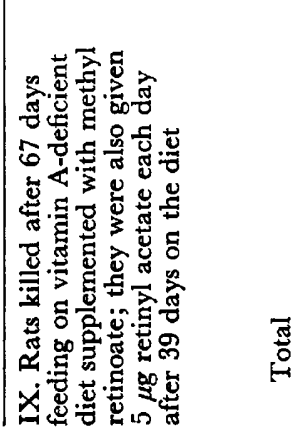 & 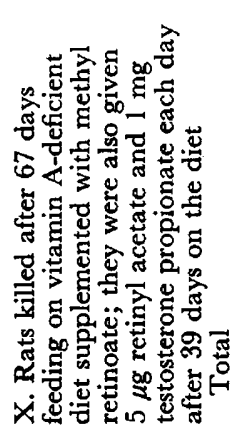 & 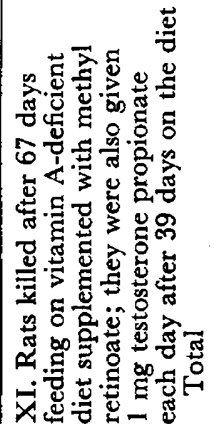 \\
\hline
\end{tabular}


At the beginning of the various treatments degenerative changes were at an early stage (group II, Table 1, and Howell et al., 1964).

At the end of the experimental period rats receiving retinyl acetate had testes which, in size and histological structure, differed little from the normal. Neither FSH nor testosterone propionate prevented the development of testicular lesions in vitamin A-deficient rats receiving methyl retinoate.

Testosterone propionate had the expected effect in that it produced an increase in size of the seminal vesicles; FsH had a similar, but smaller effect, presumably due to contamination with $\mathbf{L H}$.

\section{The effect of oestrone and progesterone on female rats}

The details of the pregnancies of the rats given various hormone treatments are given in Table 2.

Only rats receiving retinyl acetate (with or without the steroid hormones) delivered litters. Oestrone and progesterone, alone or together, neither allowed litters to be born nor affected the course of resorption in rats given the vitamin A-deficient diet and methyl retinoate.

\section{DISCUSSION}

The previous observations (Thompson et al., 1961a, b, 1964), that rats fed a semi-synthetic diet, deficient in retinol but containing retinoic acid, were unable to reproduce, have been confirmed: male rats maintained with retinoic acid had testes with severely degenerate tubules (Howell et al., 1963) and female rats invariably resorbed their foetuses during the last week of pregnancy (Howell et al., 1964).

Degenerative changes in the seminiferous tubules of male rats maintained with methyl retinoate were not ameliorated by injections of testosterone propionate that stimulated over-development of the seminal vesicles (see Table 1)

\section{EXPLANATION OF PLATE 1}

CLASSIFICATION OF HISTOLOGICAL APPEARANCE OF TESTIS TUBULES

Type A: Complete spermatogenesis in all tubules.

Type B: Complete spermatogenesis in most tubules; a few tubules lacked spermatids and spermatocytes (Pl. 1, Fig. 1).

Type C: Many tubules showed complete spermatogenesis, some contained early spermatid stages and in a few there was a severe loss of germinal epithelium (Pl. 1, Fig. 2).

Type D: There was severe loss of germinal epithelium. Many tubules were lined by Sertoli cells and spermatogonia. In some tubules spermatocytes were numerous but few spermatids were present. Some tubules did not have a lumen and the cytoplasm lining many of the tubules was vacuolated (Pl. 1, Fig. 3 ).

Type E: Most of the tubules were lined by Sertoli cells and spermatogonia: spermatocytes were rare and spermatids absent. Some tubules did not have a lumen and the cytoplasmic lining of others was vacuolated (Pl. 1, Fig. 4).

FIG. 1. Section of a testis showing some spermatid and spermatocyte loss in three tubules; the others are normal. Type $B$ in Table $1 . \mathrm{H} \& \mathrm{E}, \times 70$.

FIg. 2. Section of a testis showing severe loss of germinal epithelium in two of the tubules. Type $\mathbf{C}$ in Table 1 . $\mathbf{H} \& \mathbf{E}, \times 70$.

Fic. 3. Section of a testis showing severe loss of germinal epithelium. Type D in Table 1. $\mathrm{H} \& \mathrm{E}, \times 70$.

FIG. 4. Section of a testis showing severe loss of germinal epithelium. Many of the tubules no longer have a lumen. Type $\mathrm{E}$ in Table 1 . H \& $\mathrm{E}, \times 70$. 


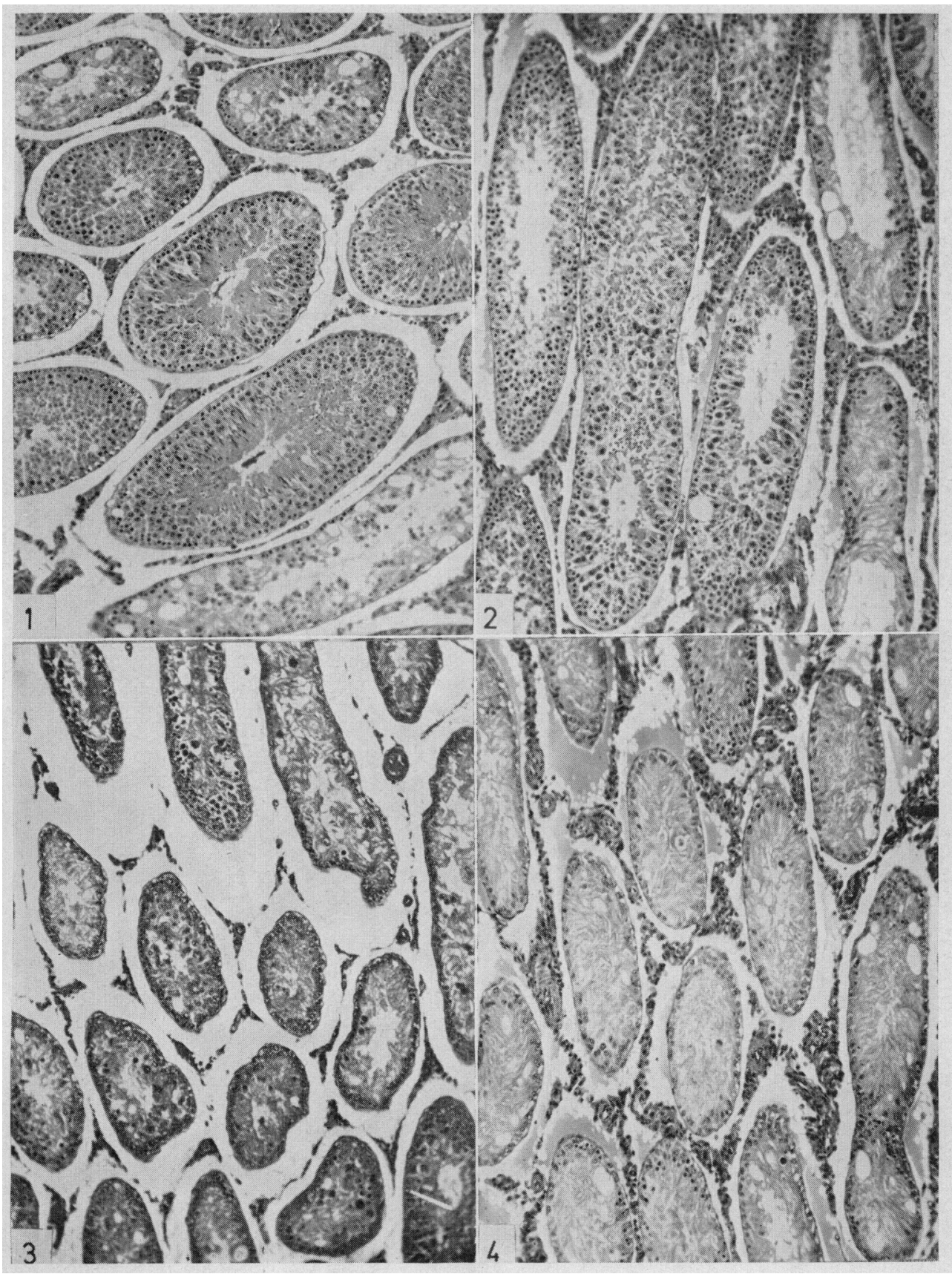

(Facing p. 314) 
or by injections of FSH. The doses of both FSH and testosterone propionate were those sufficient to maintain spermatogenesis in hypophysectomized rats (Simpson, Li \& Evans, 1951; Albert 1960).

Small amounts of retinol were effective in maintaining spermatogenesis in these rats. The absence of retinol cannot, therefore, affect the seminiferous epithelium indirectly by a reduction in the secretion of FSH by the pituitary or of androgen by the interstitial cells of the testis. The failure of spermatogenesis in retinol-deficient rats appears to be due to a more direct requirement for retinol.

TABLE 2

EFFECT OF INJECTIONS OF PROGESTERONE AND OESTRONE ON PREGNANGY IN VITAMIN A-DEFICIENT RATS MAINTAINED ON METHYL RETINOATE

\begin{tabular}{|c|c|c|c|c|c|c|}
\hline \multirow{2}{*}{$\begin{array}{c}\text { Treatment } \\
\text { (daily from } \\
\text { 8th to } 20 \text { th days } \\
\text { after mating) }\end{array}$} & \multirow{2}{*}{$\begin{array}{l}\text { No. of rats } \\
\text { mated }\end{array}$} & \multirow{2}{*}{$\begin{array}{l}\text { No. of rats } \\
\text { producing } \\
\quad \text { litters }\end{array}$} & \multirow{2}{*}{$\begin{array}{l}\text { No. of rats } \\
\text { resorbing } \\
\text { foetuses }\end{array}$} & \multicolumn{3}{|c|}{ No. of young in each litter } \\
\hline & & & & Living & Dead & Total \\
\hline $5 \mu \mathrm{g}$ retinyl acetate & 10 & 6 & 0 & $\begin{array}{r}0 \\
7 \\
10 \\
10 \\
9 \\
5\end{array}$ & $\begin{array}{l}2 \\
0 \\
1 \\
0 \\
0 \\
0\end{array}$ & $\begin{array}{r}2 \\
7 \\
11 \\
10 \\
9 \\
5\end{array}$ \\
\hline $\begin{array}{l}5 \mu \mathrm{g} \text { retinyl acetate } \\
4 \mathrm{mg} \text { progesterone }\end{array}$ & 10 & 7 & 0 & $\begin{array}{l}3 \\
0 \\
7 \\
6 \\
8 \\
7 \\
5\end{array}$ & $\begin{array}{l}2 \\
2 \\
0 \\
2 \\
0 \\
2 \\
3\end{array}$ & $\begin{array}{l}5 \\
2 \\
7 \\
8 \\
8 \\
9 \\
8\end{array}$ \\
\hline $4 \mathrm{mg}$ progesterone & 10 & 0 & 9 & - & - & - \\
\hline $\begin{array}{l}5 \mu \mathrm{g} \text { retinyl acetate } \\
1 \mu \mathrm{g} \text { oestrone }\end{array}$ & 10 & 6 & 0 & $\begin{array}{l}5 \\
6 \\
7 \\
6 \\
6 \\
1\end{array}$ & $\begin{array}{l}0 \\
3 \\
0 \\
2 \\
0 \\
0\end{array}$ & $\begin{array}{l}5 \\
9 \\
7 \\
8 \\
6 \\
1\end{array}$ \\
\hline $1 \mu \mathrm{g}$ oestrone & 10 & 0 & 7 & - & - & - \\
\hline $\begin{array}{l}1 \mu \mathrm{g} \text { oestrone } \\
4 \mathrm{mg} \text { progesterone }\end{array}$ & 10 & 0 & 5 & - & - & - \\
\hline No treatment & 10 & 0 & 9 & - & - & - \\
\hline
\end{tabular}

The existence of specific changes in the seminiferous epithelium of vitamin A-deficient rats was recognized by Mason (1939), who found that administration of pregnancy urine or implantation of pituitary tissue did not prevent the degeneration of the testes, although they did stimulate enlargement of the seminal vesicles. Similar observations on animals with orthodox vitamin A deficiency were made by van Os (1936) with pregnancy urine, Mayer \& Truant (1949) with testosterone and Mayer \& Goddard (1951) using chorionic gonadotrophin. The decreased size of the seminal vesicles and other accessory 
organs in rats subjected to vitamin A deficiency has been ascribed to inanition (Mason, 1939) which reduces the level of circulating hypophysial gonadotrophins (Leathem, 1958). Our rats, maintained on methyl retinoate, had a normal food intake; thus the small size of the seminal vesicles in vitamin A deficiency cannot be ascribed entirely to inanition.

The reduction in size of the accessory sexual organs may be a consequence of the primary change in the germinal epithelium. Thus, in cryptorchid rats (Nelson, 1937) and in rats maintained with methyl retinoate, degeneration of the tubular epithelium is accompanied by atrophy of the seminal vesicles.

The gradual loss of vision in retinol-deficient rats maintained on retinoic acid (Dowling \& Wald, 1960) may be a complicating factor. Browman (1940), using rats from which the eyes had been removed at birth, and Fiske (1941), using rats kept in constant darkness, showed that lack of visual stimulation resulted in a reduction in seminal vesicle size compared with normal controls.

Female rats, maintained with methyl retinoate, resorbed their foetuses even when the ovarian hormones, progesterone and oestrone, were injected together or separately. The quantities administered were those previously reported to maintain pregnancy in rats ovariectomized and hypophysectomized on the 8th day of pregnancy (Lyons, 1943). When small quantities of retinol were given, pregnancies were completed. Thus in the female rat, as in the male, retinol appears to have a specific and direct effect on reproduction which is not mediated through the endocrine system.

These results are compatible with the opinion of Thompson et al. (1964) that it is not possible to explain the salient features of the reproductive failure in terms of an obvious or simple endocrine insufficiency.

Our results contrast with the observations of Scott \& Scott (1964) who reported a 'surge of meiotic divisions' in the seminiferous tubules of vitamin A deficient cats in response to gonadotrophins, and also with those of Hays \& Kendall (1956) who found that pregnancy was maintained in vitamin Adeficient rabbits when progesterone was administered. These results do not necessarily indicate a species difference since the thoroughness of the vitamin A depletion and the specificity of the responses to the endocrine treatment are variously open to question. It is noteworthy that injections of ovarian hormones have been shown to be beneficial during pregnancy if given to pyridoxinedeficient rats (Nelson, Lyons \& Evans, 1951); to rats fed diet low in protein (Nelson \& Evans, 1954); and to rats fed sucrose only throughout pregnancy (Kendall \& Hays, 1960).

It seems probable that unequivocal evidence for a specific function of retinol in the reproduction of higher animals will be obtained only by using rigorously defined diets completely free of retinol but containing retinoic acid.

\section{ACKNOWLEDGMENTS}

We wish to thank Professor D. L. Hughes and Professor R. A. Morton, F.R.s., for their encouragement and advice, Mrs M. W. Harling, A.I.M.L.T., and Miss P. McMahon for technical assistance, Mr G. Weston, F.I.M.L.T., and Mr E. O'Neil for the photographs and Dr O. Isler of F. Hoffmann-La Roche \& Co., 
Basel, for gifts of retinoic acid. This work was supported in part by United States Public Health Service Grant AM-05282-02. W.A.G. is in receipt of an Agricultural Research Council Research Studentship and J.N.T. is a British Egg Marketing Board Fellow.

\section{REFERENCES}

Albert, A. (1960) The mammalian testis. Sex and Internal Secretions, 3rd edn. Ed. W. C. Young. Williams \& Wilkins, Baltimore.

ARENs, J. F. \& van Dorp, D. A. (1946) Synthesis of some compounds possessing vitamin A activity. Nature, Lond. 157, 190.

Browman, L. G. (1940) The effect of optic enucleation in the male albino rat. Anat. Rec. 78, 59.

Dowlrng, J. E. \& Wald, G. (1960) The biological function of vitamin A acid. Proc. natn. Acad. Sci. U.S.A. 46, 587.

FisKe, V. M. (1941) Effect of light on sexual maturation, estrous cycles and anterior pituitary of rat. Endocrinology, 29, 187.

HAYs, R. E. \& Kendall, K. A. (1956) The beneficial effect of progesterone on pregnancy in the vitamin A deficient rabbit. $\mathcal{7}$. Nutr. 59, 337.

High, E. G., Moore, Y. E., Collins, J. D. \& Frazier, H. M. (1964) Effects of vitamin A acid on growth, reproduction and some tissues in the rat. Fedn Proc. Fedn Am. Socs exp. Biol. 23, 294.

Howell, J. McC., Thompson, J. N. \& Pitt, G. A. J. (1963) Histology of the lesions produced in the reproductive tract of animals fed a diet deficient in vitamin $\mathrm{A}$ alcohol but containing vitamin $\mathrm{A}$ acid. I. The male rat. F. Reprod. Fert. 5, 159.

Howell, J. McC., Thompson, J. N. \& Pitt, G. A. J. (1964) Histology of the lesions produced in the reproductive tract of animals fed a diet deficient in vitamin A alcohol but containing vitamin $\mathrm{A}$ acid. II. The female rat. 7. Reprod. Fert. 7, 251.

Juneja, H. S., Murthy, S. K. \& Ganguly, J. (1964) Effect of retinoic acid on the reproductive performance of male and female rats. Indian F. exp. Biol. 2, 153.

Kendall, K. A. \& Hays, R. L. (1960) Maintained pregnancy in the rat as associated with progesterone administration and multiple-nutrient deficiency. F. Nutr. 70, 10.

Leathem, J. H. (1958) Extragonadal factors in reproduction. Recent Progress in the Endocrinology of Reproduction. Ed. C. W. Lloyd. Academic Press, New York.

Lyons, W. R. (1943) Pregnancy maintenance in hypophysectomized-öophorectomised rats injected with oestrone and progesterone. Proc. Soc. exp. Biol. Med. 54, 65.

MAson, K. E. (1939) Relation of the vitamins to the sex glands. Sex and Internal Secretions, 2nd edn. Eds. E. Allen, C. H. Darnforth and E. A. Doisy. Williams \& Wilkins, Baltimore.

MAYER, J. \& GoDdard, J. W. (1951) Effects of administration of gonadotropic hormone on vitamin A-deficient rats. Proc. Soc. exp. Biol. Med. 76, 149.

MAYeR, J. \& TRUANT, A. P. (1949) Effects of administration of testosterone on vitamin A-deficient rats. Proc. Soc. exp. Biol. Med. 72, 436.

NeLson, M. N. \& Evans, H. M. (1954) Maintenance of pregnancy in the absence of dietary protein with oestrone and progesterone. Endocrinology, 55, 543 .

Nelson, M. N., Lyons, W. R. \& Evans, H. M. (1951) Maintenance of pregnancy in pyridoxine deficient rats injected with oestrone and progesterone. Endocrinology, 48, 725.

NELSON, W. O. (1937) Some factors involved in the control of the gametogenic and endocrine functions of the testis. Cold Spring Harb. Symp. quant. Biol. 5, 123.

Os, P. M. van (1936) The influence of the gonadotropic hormone from the urine on the testis with degenerated seminal tubules. Acta brev. neerl. Physiol. 6, 151.

RedfeArn, E. R. (1960) The metabolism of vitamin A acid and its $\mathbf{C}_{25}$ homologue. Archs Biochem. Biophys. 91, 226.

ScotT, P. P. \& Scott, M. G. (1964) Vitamin A and reproduction in the cat. J. Reprod. Fert. 8, 270.

Sharman, I. M. (1949) The biological activity and metabolism of vitamin A acid. F. Nutr. 3, viii.

Simpson, M. E., Lr, C. H. \& Evans, H. M. (1951) Synergism between pituitary follicle stimulating hormone and human chorionic gonadotropin. Endocrinology, 48, 370.

Thompson, J. N., Howell, J. McC. \& PitT, G. A. J. (1961a) Vitamin A acid and reproduction in male rats. Biochem. $\mathcal{J} .80,25$.

Thompson, J. N., Howell, J. MaG. \& Pitt, G. A. J. (1961b) The inability of vitamin A acid to replace vitamin A in pregnant female rats. Biochem. F. 80, 16r.

Thompson, J. N., Howell, J. McC. \& Pitt, G. A. J. (1964) Vitamin A and reproduction in rats. Proc. R. Soc. B, 159, 510. 